\title{
Erratum to: Animal and cellular models of familial dysautonomia
}

\author{
Frances Lefcort $^{1}$ (D) $\cdot$ Marc Mergy $^{1} \cdot \operatorname{Sarah}$ B. Ohlen ${ }^{1} \cdot$ Yumi Ueki $^{1}$. \\ Lynn George ${ }^{2}$
}

Published online: 17 July 2017

(C) Springer-Verlag GmbH Germany 2017

\section{Erratum to: Clin Auton Res \\ DOI 10.1007/s10286-017-0438-2}

Unfortunately, the section "Acknowledgements" was not included in the original publication. It is now included here.

Acknowledgements F.L. was supported by National Institutes of Health R01 NS086796 and grants from the Dysautonomia Foundation. L.G. was supported by National Institutes of Health R15NS090384.

The online version of the original article can be found under doi:10.1007/s10286-017-0438-2.

Frances Lefcort

lefcort@montana.edu

1 Department of Cell Biology and Neuroscience, Montana State University, Bozeman, MT 59717, USA

2 Department of Biological and Physical Sciences, Montana State University Billings, Billings, MT 59101, USA 